\title{
Media Policy, Media Reform and Media Power: An Interview with Des Freedman ${ }^{1}$
}

\author{
SIMON DAWES, Université Paul Valéry, Montpellier, France
}

DES FREEDMAN, Goldsmiths College, London

\begin{abstract}
In this interview, Des Freedman discusses his work as an activist in the Media Reform movement, as a critic of media policy, and as a theorist of media power. Freedman explains his approach to media power as a material and relational property, distinguishing it from liberal pluralist, cultural studies and political-economic approaches. Discussing media power in the context of the recent $\mathrm{BBC}$ charter review process and the earlier Leveson Inquiry into the ethics of the British press, Freedman clarifies his proposal for a research focus on 'nondecisionmaking' in the policy field. Ultimately, he explains how guiding principles, programmes of action, and an understanding of the contradictory nature of media power are all necessary to bring about revolutionary reform.
\end{abstract}

\section{KEYWORDS}

BBC, Leveson Inquiry, Media Policy, Media Power, Media Reform, Neoliberalism

SIMON DAWES: In your recent book, The Contradictions of Media Power (2014), you argue that your radical approach to critiquing media power compensates for the 'misplaced optimism' of liberal pluralism (or what you call the consensus paradigm), the 'unwarranted celebrations' of fan studies or cultural studies approaches (the chaos paradigm), and the 'occasional functionalism' of a political-economic approach (the control paradigm). Could you begin by explaining briefly the most significant differences between your contradiction paradigm and these alternative approaches?

DES FREEDMAN: The contradiction paradigm puts struggle at the heart of the social world. I don't mean that we spend all our time fighting over processes of social reproduction but simply that they are incredibly unstable, open to challenge and far from predictable in their resolution. The contradiction paradigm argues that instability is a systemic feature of modern capitalism - not an accident of bad management, hyperactive technologies or partisan journalism. And furthermore, it offers an invitation to exploit this instability, to deepen the

\footnotetext{
${ }^{1}$ This interview is part of a special section of interviews on 'Neoliberalism, Media and Power', edited by Simon Dawes and also featuring interviews with Terry Flew and Sean Phelan. Available at: http://ojs.meccsa.org.uk/index.php/netknow/issue/archive
} 
fissures and to see social reproduction not as something that is done to us but as a constant source of tension for all those involved.

Of course it's also about different conceptions of power. Forgive my generalisations, but while the consensus paradigm seeks to 'flatten' power (seen by Talcott Parsons as "a generalised facility or resource in society"), chaos acknowledges instability but then underplays the structural disparities that shape how these struggles will play out. Control does the opposite: it places these disparities at the heart of its understanding of the social world but sometimes does this at the expense of recognising the contingency and fragility of the whole operation.

To be honest, I understand the attraction of all of these approaches. How could you fail to notice the yearning for an overarching English, British or European identity over the last few months? How could you also fail to see the volatility of contemporary politics and the way that 'mainstream media' have failed to engage audiences in the way that less centralised forms of communication are sometimes able to do? And how could you fail to want to highlight the material interests that lie behind the motivations of powerful agenda-setters in the recent referenda? But what I really want to do is to emphasise the fundamentally contradictory nature of human experience under capitalism, and to try to show how the media cannot totally ignore the very simple fact that audiences have a very ambivalent attitude towards powerful institutions that is marked at times by willing consent, at other times by grumpy indifference and at other times by outright hostility.

SIMON DAWES: More specifically, you view media power as a material and relational property, and analyse it in relation to other actors and other forms of power, recognising that although power precedes its mediation, media power is still a form of power in its own right. Could you explain what you mean by material and relational, and how media power is more than just the mediation of power?

DES FREEDMAN: Power relates to a capacity to act that is unevenly distributed. It is material because it relates to the structures that are crucial in shaping these patterns of distribution - things like class, gender and ethnicity - and crucial in determining whether your actions will have consequences. Mark Zuckerberg's actions will have rather more consequences than anything I ever do. But what I also want to stress is that these structures aren't autonomous but interconnected in terms of how they shape social reproduction perhaps through the state, perhaps through private transactions in the market (that are nevertheless also shaped by the state), perhaps through much more domestic and intimate structures. Media power is relational in the sense that it is not something wielded exclusively by individuals but through different networks (and I don't just mean technological networks) that determine the conditions in which media production and consumption take place something that the best forms of critical political-economy are great at highlighting. The revelations that came out of the Leveson Inquiry about the collusion between senior 
politicians, news executives and police is a perfect example of the contemporary dynamics of media power which is why, by the way, I think we need Leveson 2 to explore these interconnections.

Having said that, I think it's important to emphasise that 'power precedes its mediation'. The ability of political and economic elites to command something called 'power' is not dependent on mediation processes but on their wider control of material and symbolic resources. Of course, it's understandable that media researchers are likely to want to focus on the latter but it's just as vital to note that power also involves the opportunity to be 'invisible'. Of course this links to a bigger debate on what you understand by 'mediation' but do you mind if we don't get into that here?

SIMON DAWES: At one point in your book, you offer a rather lengthy definition of media power as a "set of relations that help organise the deployment of symbolic resources that play $a$ vital role in social reproduction that, in conjunction with other institutions and processes, help to structure our knowledge about, our ability to participate in and our capacity to change the world (2014, 30, emphases added). Has your view of media power become more qualified and indirect over time? Have you increasingly focused on the relational (and contradictory) as well as the material aspects in an effort to avoid the 'occasional' functionalism of politicaleconomy approaches? And is this partly the result of engaging with critiques of the control paradigm, or with celebratory accounts of social media and claims that that there has been a shift in how power operates $(2014,89)$ ?

DES FREEDMAN: What a great question. The honest answer is maybe. But I think that comes less from any frustration with the potential shortcomings of political-economy approaches or that I have a sneaky regard for the more extravagant claims made by some social media theorists than by my practical activities in the media reform movement. In other words, I believe that, for the most part, political-economy provides a very thorough (and in terms of critical theory, the most comprehensive) overview of the balance of power in the media field - the increasing control of communicative capacity by large corporations; the capture of the policy field by neoliberal sets of ideas; the increasingly commodified nature of communicative exchanges - but that we might need to look beyond it in order to figure out how to challenge these processes.

SIMON DAWES: In distinguishing your approach from that of others, you're particularly critical of Michael Schudson's claim that the critique of media influence has been exaggerated, as well as Brian McNair's 'caricature' of the 'control paradigm'. But isn't it fair to say that there is a tendency among media studies scholars to over-privilege the influence of particular media moguls or corporations (as well as the media more generally)? And, although you criticise McNair's caricature, wouldn't it be fair to say that the consensus and chaos 
paradigms are also as nuanced and heterogeneous as the control paradigm? Indeed, doesn't your own focus on contradictions acknowledge that influence and control are more complex than political-economists often allow?

DES FREEDMAN: I've already argued that there is a danger of overstating processes of mediation in social reproduction more generally. But that doesn't mean at all that we shouldn't take very seriously the ability of the media to mis-represent, mis-conceive and misinform. Obviously, this is a very uneven picture and there is no single media outlet dedicated to these purposes! Media influence is a very tricky thing to assess and it has to be fully contextualised, but bear in mind that there has been a growing refrain in recent years that 'media power' is something we shouldn't worry about. Of course, Rupert Murdoch is the most famous proponent of this: the man who tweeted that 'no one controls the media or will ever again' because of the rise of the internet. So I do think we should worry about it because the internet has produced new oligopolies as opposed to getting rid of them forever. Having said that, we shouldn't 'over-privilege' the influence of individual moguls, if that means that we then see media power only as the individual property of a handful of media moguls, when it refers to relations and capacities that are more deeply embedded into social relations (though, just to make it clear, without being the fundamental driving force of social relations).

And yes, you're probably right to point out that there are discrepancies and tensions within all schools, paradigms and disciplines that mean that I'm as guilty of caricature as McNair or Chomsky. But, as I argued in the book, the key is less about who fits into a particular paradigm than about the overall dynamic of each discipline and how each relates to flows of power. I'm sure I have written a lot that would sit comfortably within the 'control' paradigm (and even within the 'consensus' one) as opposed to 'contradiction'. None of that renders the need for analytical categories any less relevant, nor those specific paradigms any less meaningful.

SIMON DAWES: Similarly, you take issue with Terry Flew's criticism of the overly generalised application of 'neoliberalism' as an object of critique. But isn't it the case that a whole range of phenomena do tend to be unreflexively dismissed as 'neoliberal' by those in the control paradigm, in particular, instead of being critically analysed? And even if one accepts the pertinence of the term 'neoliberal', isn't there a theoretical and methodological issue with how one understands the term; whether as ideology or governmentality, for instance?

DES FREEDMAN: Life is short (and the workload heavy) and we are all guilty of generalisations and simplifications. Of course, some people may use the term 'neoliberal' to refer to things they don't like and they may not always clarify the distinctions between its status as a form of ideology or governmentality. But give me a better word. We have lots of portmanteau terms that point to phenomena with internal contradictions - capitalism, equality, democracy - but I continue to use these terms while acknowledging that I need to be precise. 
If someone is 'unreflexive' in their use of 'neoliberal', then that's a shame and they shouldn't be lazy. But that doesn't mean that the term itself has lots its power or its efficacy to the situations in which we find ourselves, where the logic of the market has entered, and suffused, all levels of social experience. If you want to read more on this, don't believe me but go and read Will Davies or Natalie Fenton or David Harvey's original introduction to neoliberalism.

SIMON DAWES: To turn to more concrete examples, you've said that the problem with the Leveson Inquiry was that it didn't engage with the underlying conditions that gave rise to phone-hacking - i.e. "a press system wedded to private profit or public influence" (2014, 134). Could you explain how an understanding of media power as both material and relational helps us understand the underlying conditions of the phone-hacking scandal?

DES FREEDMAN: Do people still remember the hacking scandal and the Leveson Inquiry? I hope so. They are both textbook accounts of the play of media power and how patterns of complicity and collusion shaped the actions (and, crucially, the in-actions) of reporters, politicians and media executives. It is the perfect illustration of how big, important, wellresourced organisations - in government, media and the state - support each other, relate to each other, employ each other and cover for each other. It is a powerful reminder of how institutional priorities help to shape newsroom cultures and how audiences are not best served by these arrangements. I should add that while Leveson addressed above all the issue of the abuse of private media power, it should be obvious - after Savile especially - that public media are not immune from these pressures either.

SIMON DAWES: The BBC's Royal Charter is currently up for its 10-year renewal, and the UK's Conservative government has recently published its White Paper (DCMS, 2016) on the future of the BBC. Though the White Paper is not as the Green Paper (DCMS, 2015) may have led us to expect, the government seems to view broadcasting regulation in terms of market failure rather than cultural value, as well as from the perspective of the BBC's most vocal critics. Indeed, you've argued that the government's assault on the BBC was "payback for the support given to the Tories by press barons during the recent general election" (Freedman 2015). To what extent do you think the charter review process can be seen as the result of the influence of people like Paul Dacre and Rupert Murdoch, as well as an instance of contradictory or relational media power?

DES FREEDMAN: The charter review process was shaped by a wholly marketised view of broadcasting. I don't know which individuals can be held responsible for this or whether this is the 'common sense' view amongst the policymaking elite. I'm sure there are lots of differences of opinion inside DCMS and the cabinet about what to do with the BBC but it is irrefutable that the BBC's rivals have been lobbying for a 'smaller' and less 'expansionist' $\mathrm{BBC}$. The overarching theme of the consultation was that the public sector needs to be seen as 
an adjunct of a more productive private sector. So you have to stop it entering into markets if it might harm commercial interests and you have to introduce a climate in which the public sector will discipline itself - internalising the neoliberal mantras of 'value' and 'efficiency' and, to a certain extent, in relation to the BBC in particular, doing the government's bidding by closing channels and cutting services.

I very much doubt that the Dacres and Murdochs of this world will think the White Paper went far enough in creating the conditions for a smaller BBC, but I remain unconvinced that there was ever the desire from within government to substantially diminish an organisation that is so crucial for UK 'soft power'. Nevertheless, it is really interesting that the BBC executive reacted to the White Paper by reducing the BBC's online presence and, of course, they still have to deal with the massive impact of the government's decision to force the BBC to act as a government department by carrying costs of free licences for the over-75s. The cuts that are going to be felt in the next few years could demoralise its workforce and render it even less able to stand up to government bullying should it wish to do so.

SIMON DAWES: The extent of lobbying, particularly from News International, was brought to public attention during the Leveson Inquiry, and the issue was raised again in the context of the Green Paper on the BBC. In terms of methodology, you've suggested that as well as analysing policy discourses and the decision-making process, researchers should also turn to such processes of non-decision making and instances of policy silences, neglect and opacity $(2014,64)$, but how practically are researchers to do that?

DES FREEDMAN: Quite a few people have asked me about the methodological implications of pursuing a focus on non-decisionmaking in the policy field. I wish I had a more decisive answer but you need to employ some specific characteristics: imagination; vision; a commitment to radical alternatives; a willingness to learn from history; and an openness to seek out examples that work in other countries and in other movements. Look at the options that are dismissed in the footnotes of consultations and read the submissions by some of the most powerful players and see what makes them nervous. This is the situation we face at the moment with campaigns over levies for new journalistic start-ups and for pay-TV companies to face retransmission charges for using public service content.

The point is that you want a mixed methods approach using elite interviews with policy framers, lobbyists and regulators as well as with activists; analysis of a range of parliamentary, industry, journalistic and technical texts; spend time in Brussels, London or Washington DC; look at all the submissions to consultations that are ignored; talk to lawyers and ask them how they think policy discourse on privacy has been shaped and what questions have been deemed to be too difficult to legislate. The key for me is to identify the main dynamics and drivers of the policy field and then to figure out the countervailing forces and ideas - the hard part is to work through the tension between them, but I'm sure others will manage it better than I've been able to. 
SIMON DAWES: As well as your academic work, you're also very active as a media reformer, responding to consultations, serving on committees, acting as a witness, attending expert seminars, providing evidence when asked $(2014,88)$, as well as all the work you do for the Media Reform Coalition - but you say that these are only one part of the policy activist's job. In what way do you also bring radical politics to questions of reform; how do you bridge your academic work with your work as an activist; and what for you is the relation between reform and revolution $(2014,135-138)$ ?

DES FREEDMAN: Well a revolution can only take place if millions of people have taken part in reform movements and have decided that they are not sufficient to achieve what they need. Otherwise, it's just words. So if you want to see meaningful change in our media or educational system, you need a set of guiding principles and then you need programmes of action. Media reform has been an essential way for me to think through conceptual questions of power and privilege and to embed them in movements and campaigns - around media ownership and representation - to rebalance our communications systems. The aim is that we might then have a media that finally looks and talks like its audiences, takes its concerns and histories seriously, and finds a way to incorporate audience activity into the media not for the purposes of a theoretical semiotic pleasure but an actual redistribution of resources and power.

Just to go back to the first question, there are some fine Marxists out there who have a far better understanding of the circulation and composition of capital than I do. However, what I've always tried to highlight is that nothing will change unless we involve people in campaigns to tackle immediate problems and develop new solutions. An emphasis on the contradictions of capitalism alerts you to the fact that ordinary people hold lots of different, and conflicting, ideas in their heads and that nothing is ever 'settled' permanently. This is especially true about the media where production and consumption habits can change drastically in periods of major uncertainty. Remember, someone once said that "all that is solid melts into air" - I just want to try and make sure that we have some pretty good ideas about what a democratic media would look like when the melting takes place.

\section{References}

Freedman, D. (2014) The Contradictions of Media Power, London: Bloomsbury Freedman, D. (2015) 'Inside the bizarre logic of the BBC review', The Conversation https://theconversation.com/inside-the-bizarre-logic-of-the-bbc-review-44814 
DCMS (2015) BBC Charter Review: public consultation (Green Paper) https://www.gov.uk/government/uploads/system/uploads/attachment data/file/445 704/BBC Charter Review Consultation WEB.pdf

DCMS (2016) A BBC for the future: a broadcaster of distinction (White Paper) https://www.gov.uk/government/publications/a-bbc-for-the-future-a-broadcaster-ofdistinction

Des Freedman is interested in the relationship between media and power together with the political and economic contexts of media policymaking and regulation. He is an editor of the Sage journal Global Media and Communication and was previously on the management committee of the COST programme A20, 'The Impact of the Internet on the Mass Media in Europe'. He was awarded an ESRC grant in 2005 to examine the dynamics of media policymaking in the UK and US. He is co-editor of the 'Universities and Capitalism' section of openDemocracy, a member of the National Council of the Campaign for Press and Broadcasting Freedom and is the current chair of the Media Reform Coalition. His latest book is The Contradictions of Media Power (Bloomsbury 2014).

Email: $\underline{\text { d.freedman@ gold.ac.uk }}$

Simon Dawes is the editor of Networking Knowledge - the Journal of the MeCCSA PGN, editorial projects \& website manager of Theory, Culture \& Society and Body \& Society, and editor of the media \& communication studies section of the Open Library of Humanities. $\mathrm{He}$ teaches at Université Paul Valéry, Montpellier, France. His research revolves around issues of media theory, history and regulation. Currently, he is writing a monograph based on his $\mathrm{PhD}$ thesis, Broadcasting and the Public-Private Dichotomy (forthcoming, Palgrave Macmillan).

Email: simondawes0@gmail.com 